\title{
Complete genome sequence of Gordonia bronchialis type strain $\left(3410^{\top}\right)$
}

\author{
Natalia Ivanova ${ }^{1}$, Johannes Sikorski ${ }^{2}$, Marlen Jando ${ }^{2}$, Alla Lapidus ${ }^{1}$, Matt Nolan ${ }^{1}$, Susan Lu- \\ cass $^{1}$, Tijana Glavina Del Rio ${ }^{1}$, Hope Tice ${ }^{1}$, Alex Copeland ${ }^{1}$, Jan-Fang Cheng ${ }^{1}$, Feng Chen ${ }^{1}$, \\ David Bruce $^{1,3}$, Lynne Goodwin ${ }^{1,3}$, Sam Pitluck ${ }^{1}$, Konstantinos Mavromatis ${ }^{1}$, Galina Ovchin- \\ nikova ${ }^{1}$, Amrita Pati ${ }^{1}$, Amy Chen ${ }^{4}$, Krishna Palaniappan ${ }^{4}$, Miriam Land ${ }^{1,5}$, Loren Hauser ${ }^{1,5}$, \\ Yun-Juan Chang ${ }^{1,5}$, Cynthia D. Jeffries ${ }^{1,5}$, Patrick Chain ${ }^{1,3}$, Elizabeth Saunders ${ }^{1,3}$, Cliff Han ${ }^{1,3}$, \\ John C. Detter ${ }^{1,3}$, Thomas Brettin ${ }^{1,3}$, Manfred Rohde ${ }^{6}$, Markus Göker ${ }^{2}$, Jim Bristow ${ }^{1}$, Jona- \\ than A. Eisen ${ }^{1,7}$, Victor Markowitz ${ }^{4}$, Philip Hugenholtz ${ }^{1}$, Hans-Peter Klenk ${ }^{2}$, and Nikos C. \\ Kyrpides $^{1 *}$ \\ ${ }^{1}$ DOE Joint Genome Institute, Walnut Creek, California, USA \\ 2 DSMZ - German Collection of Microorganisms and Cell Cultures GmbH, Braunschweig, \\ Germany \\ ${ }^{3}$ Los Alamos National Laboratory, Bioscience Division, Los Alamos, New Mexico, USA \\ ${ }^{4}$ Biological Data Management and Technology Center, Lawrence Berkeley National \\ Laboratory, Berkeley, California, USA \\ ${ }^{5}$ Oak Ridge National Laboratory, Oak Ridge, Tennessee, USA \\ ${ }^{6} \mathrm{HZI}$ - Helmholtz Centre for Infection Research, Braunschweig, Germany \\ ${ }^{7}$ University of California Davis Genome Center, Davis, California, USA
}

*Corresponding author: Nikos C. Kyrpides

Keywords: obligate aerobic, human-pathogenic, endocarditis, Gram-positive, non-motile, Gordoniaceae, GEBA

Gordonia bronchialis Tsukamura 1971 is the type species of the genus. G. bronchialis is a human-pathogenic organism that has been isolated from a large variety of human tissues. Here we describe the features of this organism, together with the complete genome sequence and annotation. This is the first completed genome sequence of the family Gordoniaceae. The 5,290,012 bp long genome with its 4,944 protein-coding and 55 RNA genes is part of the Genomic Encyclopedia of Bacteria and Archaea project.

\section{Introduction}

Strain $3410^{\mathrm{T}}$ (= DSM $43247=$ ATCC $25592=\mathrm{JCM}$ 3198 ) is the type strain of the species Gordonia bronchialis, which is the type species of the genus. The genus Gordonia (formerly Gordona) was originally proposed by Tsukamura in 1971 [1]. The generic name Gordona has been chosen to honor Ruth E. Gordon, who studied extensively ' $\mathrm{Myco-}$ bacterium' rhodochrous (included later as a member of Gordona) [1]. In 1977, it was subsumed into the genus Rhodococcus [2], but revived again in 1988 by Stackebrandt et al. [3]. At the time of writing, the genus contained 28 validly published species [4]. The genus Gordonia is of great interest for its bioremediation potential [5]. Some species of the genus have been used for the decontamina- tion of polluted soils and water [6,7]. Other species were isolated from industrial waste water [8], activated sludge foam [9], automobile tire [10], mangrove rhizosphere [11], tar-contaminated oil [12], soil [13] and an oil-producing well [7]. Further industrial interest in Gordonia species stems from their use as a source of novel enzymes $[14,15]$. There are, however, quite a number of Gordonia species that are associated with human and animal diseases [16], among them G. bronchialis. Here we present a summary classification and a set of features for G. bronchalis $3410^{\mathrm{T}}$, together with the description of the complete genomic sequencing and annotation. 


\section{Classification and features}

Strain $3410^{\mathrm{T}}$ was isolated from the sputum of a patient with pulmonary disease (probably in Japan) [1]. Further clinical strains in Japan have been isolated from pleural fluid, tumor in the eyelid, granuloma, leukorrhea, skin tissue and pus [17]. In other cases, G. bronchialis caused bacteremia in a patient with a sequestrated lung [18] and a recurrent breast abscess in an immunocompetent patient [19]. Finally, G. bronchialis was isolated from sternal wound infections after coronary artery bypass surgery [20]. G. bronchialis shares 95.8-98.7\% 16S rRNA gene sequence simi- larity with the other type strains of the genus Gordonia, and 95.3-96.4\% with the type strains of the neighboring genus Williamsia.

Figure 1 shows the phylogenetic neighborhood of for $G$. bronchialis $3410^{\mathrm{T}}$ in a $16 \mathrm{~S}$ rRNA based tree. The sequences of the two 16S rRNA gene copies in the genome of $G$. bronchialis $3410^{\mathrm{T}}$, differ from each other by one nucleotide, and differ by up to 5 nucleotides from the previously published $16 \mathrm{~S}$ rRNA sequence from DSM 43247 (X79287). These discrepancies are most likely due to sequencing errors in the latter sequence.

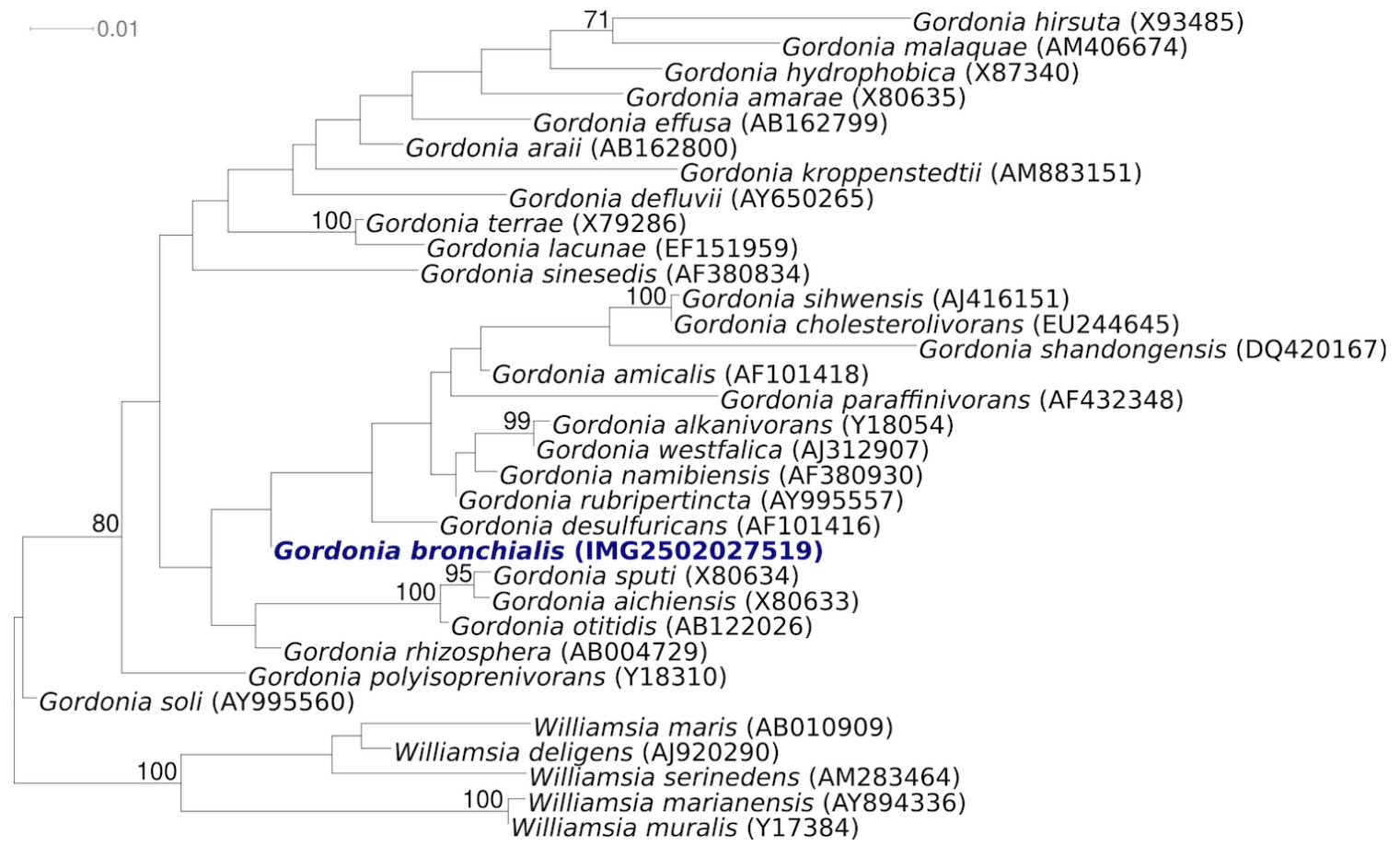

Figure 1. Phylogenetic tree highlighting the position of $G$. bronchialis $3410^{\top}$ relative to the other type strains within the genus Gordonia. The tree was inferred from 1,446 aligned characters [21,22] of the $16 \mathrm{~S}$ rRNA gene sequence under the maximum likelihood criterion [23] and rooted with the type strains of the neighboring genus Williamsia. The branches are scaled in terms of the expected number of substitutions per site. Numbers above branches are support values from 1,000 bootstrap replicates if larger than $60 \%$. Lineages with type strain genome sequencing projects registered in GOLD [24] are shown in blue, published genomes in bold.

In a very comprehensive study, Tsukamura analyzed a set of 100 quite diverse characters for 41 G. bronchialis strains isolated from sputum of patients with pulmonary disease, including the type strain [1]. Unfortunately, this study does not present the characteristics of the type strain $3410^{\mathrm{T}}$ as such. We nevertheless first present these data, as this study gives a good overview of the species itself. In order to summarize the data here, we regard positive reactions in more than 34 strains as positive, and positive reactions in only 13 or less strains as negative. Most characters, however, are either clearly positive (40 or 41 strains) or clearly negative (0 or 1 strains). The detailed methods are reported elsewhere $[25,26]$.

G. bronchialis is Gram-positive (Table 1) and shows slight but not strong acid-fastness. A mycelium is not observed. G. bronchialis strains are non-motile and produce neither conidia nor endospores $[1,3]$. G. bronchialis is an obligately aero- 
bic chemoorganotroph with an oxidative-type metabolism [3].The cells are rod-shaped and show compact grouping (like a cord) (Figure 2), and provide a rough colonial morphology with pinkish-brown colony pigmentation [1]. Photochromogenicity was not observed. G. bronchialis grows quite rapidly [1], with visible colonies appearing within 1-3 days $[1,36]$. G. bronchialis is positive for catalase and nitrate reduction, but arylsulphatase (3 days and 2 weeks), salicylate and PAS degradation was not observed [1]. Growth occurs on $0.2 \%$ sodium p-aminosalicylate and 62.5 and $125 \mu \mathrm{g}$ $\mathrm{NH}_{2} \mathrm{OH}-\mathrm{HCl} / \mathrm{ml}$, but not with 250 or $500 \mu \mathrm{g}$. G. bronchialis is tolerant to both 0.1 and $0.2 \%$ picric acid. G. bronchialis grows at $28^{\circ} \mathrm{C}$ and $37^{\circ} \mathrm{C}$, but not at $45^{\circ} \mathrm{C}$ or $52^{\circ} \mathrm{C}$ [1]. G. bronchialis is positive for acetamidase, urease, nicotinamidase and pyrazinamidase, but negative for benzamidase, isonicotinamidase, salicylamidase, allanoinase, succinamidase, and malonamidase [1]. G. bronchialis utilizes acetate, succinate, malate, pyruvate, fumarate, glycerol, glucose, mannose, trehalose, inositul, fructose, sucrose, ethanol, propanol, and propylene glycol as a carbon source for growth, but not citrate, benzoate, malonate, galactose, arabinose, xylose, rhamnose, raffinose, mannitol, sorbitol, or various forms of butylene glycol $(1,3-; 1,4-$; 2,3-) [1]. G. bronchialis utilizes L-glutamate and acetamide as a $\mathrm{N}-\mathrm{C}$ source, but not L-serine, benzamide, monoethanolamine or trimethylene diamine. Glucosamine is utilized by 18 strains [1]. $G$. bronchialis utilizes as nitrogen source L-glutamate, L-serine, L-methionine, acetamide, urea, pyrazinamide, isonicotinamide, nicotinamide, succinamide, but not benzamide and nitrite. Nitrate is utilized by 25 strains as nitrogen source [1]. G. bronchialis strains do not produce nicotinic acid. G. bronchialis strains do not grow on TCH medium $(10 \mu \mathrm{g} / \mathrm{ml})$ or on salicylate medium $(0.05 \%$ and $0.01 \%)$ [1].

In the following, characteristics of the type strain $3410^{\mathrm{T}}$ are presented: strain $3410^{\mathrm{T}}$ reduces nitrate and hydrolyses urea, but it does not hydrolyze aesculin, allantoin or arbutin [37]. It decomposes $(\%, w / v)$ starch (1) and uric acid (0.5), but not hypoxanthine (0.4), tributyrin (0.1), tween 80 (1), tyrosine (0.5) and xanthine (0.4) [37]. It grows on glycerol (1) and sodium fumarate (1) as sole carbon sources $(\%, w / v)$, but not on arbutin (1), Dcellobiose (1), N-acetyl-D-glucosamine (0.1), adipic acid (0.1), betaine (0.1), oxalic acid (0.1), propan-1-ol (0.1) [37]. Strain 3410 ${ }^{\mathrm{T}}$ grows in the presence $(\% \mathrm{w} / \mathrm{v})$ of oleic acid (0.1) and zinc chloride (0.001) [37].
In an API ZYM test, strain $3410^{\mathrm{T}}$ reacts positively for alkaline phosphatase, butyrate esterase, leucine arylamidase and naphtol-AS-BI-phosphohydrolase, but not for caprylate esterase, cystine arylamidase, $\beta$-glucosidase, myristate lipase, and valine arylamidase [13]. Complementary to the results of Tsukamura [1], strain $3410^{\mathrm{T}}$ utilizes as sole carbon source $\mathrm{D}(+)$ cellobiose, $\mathrm{D}(+)$ galactose, $\mathrm{D}(+)$ mannose, meso-inositol, $\mathrm{L}(+)$ rhamnose and sodium succinate, but not $\mathrm{D}(-)$ lactose, $\mathrm{D}(-)$ ribose, sodium benzoate and sodium citrate [38]. The use of $\mathrm{D}(+)$ galactose [38] might contrast above reported results from Tsukamura [1]. L-threonine and L-valinine are used as sole nitrogen source by strain $3410^{\mathrm{T}}$, but not L-asparagine, L-proline and Lserine [38]. Interestingly, Tsukamura reports that 40 out of 41 strains utilize L-serine as sole nitrogen source [1], and it is not clear if the only negative strain in the Tsukamura study could be the type strain $3410^{\mathrm{T}}$ [1].

In the BiOLOG system, strain $3410^{\mathrm{T}}$ reacts positively for $\alpha$-cyclodextrin, $\beta$-cyclodextrin, dextrin, glycogen, maltose, maltotriose, D -mannose, 3methyl glucose, palatinose, $\mathrm{t}$-raffinose, salicin, turanose, D-xylose, L-lactic acid, methyl succinate, $\mathrm{N}$ acetyl- L-glutamic acid [12], but not for $N$ acetylglucosamine, amygdalin, D-arabitol, L-Rhamnose, D-ribose, D-sorbitol, D-trehalose, acetic acid, $\alpha$ hydroxybutyric acid, $\beta$-hydroxybutyric acid, $\alpha$ ketoglutaric acid, $\alpha$-ketovaleric acid, s-lactic acid methyester, L-malic acid, propionic acid, succinamic acid, alaninamide, t-alanine and glycerol [12]. Further carbon source utilization results are published elsewhere [8].

Drug susceptibility profiles of 13 G. bronchialis strains from clinical samples have been examined in detail [17], but they are too complex to summarize here. No significant matches with any $16 \mathrm{~S}$ rRNA sequences from environmental genomic samples and surveys are reported at the NCBI BLAST server (November 2009).

\section{Chemotaxonomy}

The cell-wall peptidoglycan is based upon mesodiaminopimelic acid (variation Al $\gamma$ ). The glycan moiety of the peptidoglycan contains $\mathrm{N}$-glycolylmuramic acid. The wall sugars are arabinose and galactose. Mycolic acids are present with a range of ca. 48-66 carbon atoms. The predominant menaquinone is MK-9(H2), with only low amounts of MK-9(H0), MK-8(H2), and MK-7(H2) [3,8,39-41]. Moreover, the cell envelope of $G$. bronchialis $3410^{\mathrm{T}}$ 
contains a lipoarabinomannan-like lipoglycan [42]. The same study also observed a second amphiphilic fraction with properties suggesting a phosphatidylinositol mannoside [42]. The cellular fatty acid composition (\%) is $\mathrm{C}_{16: 0}$ (23), tuberculostearic acid (20), $\mathrm{C}_{16: 1 \text { cis9 }}(16), \mathrm{C}_{16: 1 \text { cis7 }}(11), \mathrm{C}_{18: 1}$ (10), and 10-methyl $C_{17: 0}$ (7). All other fatty acids are at $3 \%$ or below [8].

Table 1. Classification and general features of G. bronchialis $3410^{\top}$ according to the MIGS recommendations [27]

\begin{tabular}{|c|c|c|c|}
\hline MIGS ID & Property & Term & Evidence code \\
\hline & \multirow{9}{*}{ Current classification } & Domain Bacteria & TAS [28] \\
\hline & & Phylum Actinobacteria & TAS [29] \\
\hline & & Class Actinobacteria & TAS [30] \\
\hline & & Order Actinomycetales & TAS $[30]$ \\
\hline & & Suborder Corynebacterineae & TAS $[30,31]$ \\
\hline & & Family Gordoniaceae & TAS [30] \\
\hline & & Genus Gordonia & TAS $[3,30,32]$ \\
\hline & & Species Gordonia bronchialis & TAS [1] \\
\hline & & Type strain 3410 & TAS [1] \\
\hline & Gram stain & positive & TAS [1] \\
\hline & Cell shape & short rods in compact grouping (cord-like) & TAS [1] \\
\hline & Motility & non-motile & TAS [1] \\
\hline & Sporulation & non-sporulating & TAS [1] \\
\hline & Temperature range & grows at $28^{\circ} \mathrm{C}$ and $37^{\circ} \mathrm{C}$, not at $45^{\circ} \mathrm{C}$ & TAS [1] \\
\hline & Optimum temperature & probably between $28^{\circ} \mathrm{C}$ and $37^{\circ} \mathrm{C}$ & TAS [1] \\
\hline & Salinity & $2.5 \%$ & TAS [33] \\
\hline \multirow[t]{3}{*}{ MIGS-22 } & Oxygen requirement & obligate aerobe & TAS [1] \\
\hline & Carbon source & mono- and disaccharides & TAS [1] \\
\hline & Energy source & chemoorganotroph & TAS [3] \\
\hline MIGS-6 & Habitat & human & TAS [1] \\
\hline MIGS-15 & Biotic relationship & free living & NAS \\
\hline \multirow[t]{3}{*}{ MIGS-14 } & Pathogenicity & opportunistic pathogen & TAS $[1,17-20]$ \\
\hline & Biosafety level & 2 & TAS [34] \\
\hline & Isolation & $\begin{array}{l}\text { sputum from human with pulmonary } \\
\text { disease in (probably) Japan }\end{array}$ & TAS [1] \\
\hline MIGS-4 & Geographic location & global & TAS $[1,17-20]$ \\
\hline MIGS-5 & Sample collection time & 1971 or before & TAS [1] \\
\hline $\begin{array}{l}\text { MIGS-4.1 } \\
\text { MIGS-4.2 }\end{array}$ & $\begin{array}{l}\text { Latitude, } \\
\text { Longitude }\end{array}$ & not reported & \\
\hline MIGS-4.3 & Depth & not reported & \\
\hline MIGS-4.4 & Altitude & not reported & \\
\hline
\end{tabular}

Evidence codes - IDA: Inferred from Direct Assay (first time in publication); TAS: Traceable Author Statement (i.e., a direct report exists in the literature); NAS: Non-traceable Author Statement (i.e., not directly observed for the living, isolated sample, but based on a generally accepted property for the species, or anecdotal evidence). These evidence codes are from of the Gene Ontology project [35]. If the evidence code is IDA, then the property was directly observed for a live isolate by one of the authors or an expert mentioned in the acknowledgements.

\section{Genome sequencing and annotation Genome project history}

This organism was selected for sequencing on the basis of its phylogenetic position, and is part of the
Genomic Encyclopedia of Bacteria and Archaea project. The genome project is deposited in the 
Genome OnLine Database [24] and the complete genome sequence is deposited in GenBank. Sequencing, finishing and annotation were per- formed by the DOE Joint Genome Institute (JGI). A summary of the project information is shown in Table 2.

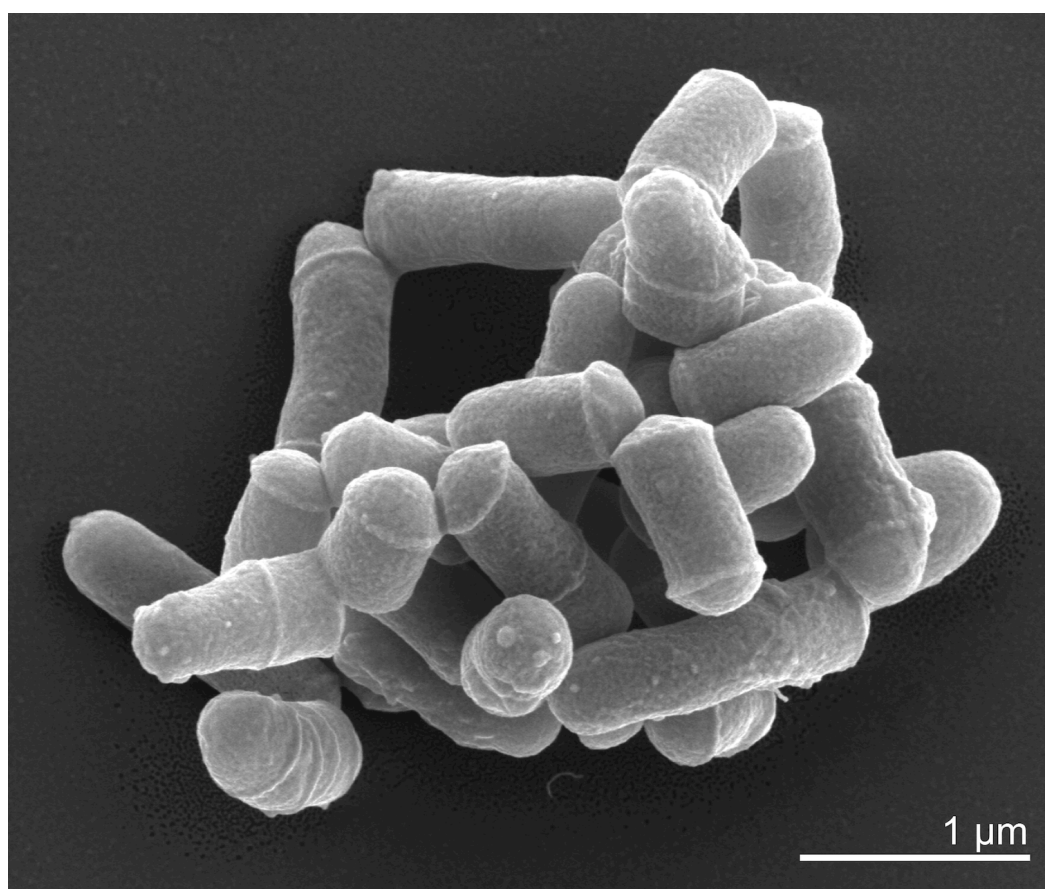

Figure 2. Scanning electron micrograph of G. bronchialis $3410^{\top}$

Table 2. Genome sequencing project information

\begin{tabular}{|c|c|c|}
\hline MIGS ID & Property & Term \\
\hline MIGS-31 & Finishing quality & Finished \\
\hline MIGS-28 & Libraries used & $\begin{array}{l}\text { Two Sanger libraries: } 8 \mathrm{~kb} \text { pMCL200 } \\
\text { and fosmid pcc1Fos } \\
\text { One } 454 \text { pyrosequence standard library }\end{array}$ \\
\hline MIGS-29 & Sequencing platforms & ABI3730, 454 GS FLX \\
\hline MIGS-31.2 & Sequencing coverage & $7.98 \times$ Sanger; $23.2 \times$ pyrosequence \\
\hline MIGS-30 & Assemblers & Newbler, phrap \\
\hline \multirow[t]{6}{*}{ MIGS-32 } & Gene calling method & Prodigal, GenePRIMP \\
\hline & INSDC ID & СР001802 \\
\hline & GenBank Date of Release & October 28, 2009 \\
\hline & GOLD ID & Gc01134 \\
\hline & NCBI project ID & 29549 \\
\hline & Database: IMG-GEBA & 2501939625 \\
\hline \multirow[t]{2}{*}{ MIGS-13 } & Source material identifier & DSM 43247 \\
\hline & Project relevance & Tree of Life, GEBA \\
\hline
\end{tabular}

\section{Growth conditions and DNA isolation}

G. bronchialis $3410^{\mathrm{T}}$, DSM 43247, was grown in DSMZ 535 [43] at $28^{\circ} \mathrm{C}$. DNA was isolated from 1$1.5 \mathrm{~g}$ of cell paste using Qiagen Genomic 500 DNA Kit (Qiagen, Hilden, Germany) following the manufacturer's instructions with modification st/LALMP for cell lysis according to Wu et al. [44].

\section{Genome sequencing and assembly}

The genome was sequenced using a combination of Sanger and 454 sequencing platforms. All general aspects of library construction and sequencing performed at the JGI can be found on the JGI website. 454 Pyrosequencing reads were assembled using the Newbler assembler version 
1.1.02.15 (Roche). Large Newbler contigs were broken into 5,776 overlapping fragments of 1,000 bp and entered into assembly as pseudo-reads. The sequences were assigned quality scores based on Newbler consensus q-scores with modifications to account for overlap redundancy and to adjust inflated q-scores. A hybrid 454/Sanger assembly was made using the parallel phrap assembler (High Performance Software, LLC). Possible mis-assemblies were corrected with Dupfinisher [45] or transposon bombing of bridging clones (Epicentre Biotechnologies, Madison, WI). Gaps between contigs were closed by editing in Consed, custom primer walk or PCR amplification. A total of 876 primer walk reactions, 12 transposon bombs, and 1 pcr shatter libraries were necessary to close gaps, to resolve repetitive regions, and to raise the quality of the finished sequence. The error rate of the completed genome sequence is less than 1 in 100,000 . Together all sequence types provided $51.2 \times$ coverage of the genome. The final assembly contains 52,329 Sanger and 508,130 pyrosequence reads.

\section{Genome annotation}

Genes were identified using Prodigal [46] as part of the Oak Ridge National Laboratory genome annotation pipeline, followed by a round of manual curation using the JGI GenePRIMP pipeline [47]. The predicted CDSs were translated and used to search the National Center for Biotechnology Information (NCBI) nonredundant database, UniProt, TIGRFam, Pfam, PRIAM, KEGG, COG, and InterPro databases. Additional gene prediction analysis and manual functional annotation was performed within the Integrated Microbial Genomes Expert Review (IMG-ER) platform [48].

\section{Genome properties}

The genome consists of a $5.2 \mathrm{Mbp}$ long chromosome and a 81,410 bp plasmid (Table 3 and Figure $3)$. Of the 4,999 genes predicted, 4,944 were protein coding genes, and 55 RNAs; 264 pseudogenes were also identified. The majority of the proteincoding genes (69.1\%) were assigned with a putative function while those remaining were annotated as hypothetical proteins. The distribution of genes into COGs functional categories is presented in Table 4.

Table 3. Genome Statistics

\begin{tabular}{lrr}
\hline Attribute & \multicolumn{1}{c}{ Value } & \% of Total \\
\hline Genome size (bp) & $5,290,012$ & $100.00 \%$ \\
DNA coding region (bp) & $4,897,508$ & $92.58 \%$ \\
DNA G+C content (bp) & $3,546,559$ & $67.04 \%$ \\
Number of replicons & 1 & \\
Extrachromosomal elements & 1 & \\
Total genes & 4,999 & $100.00 \%$ \\
RNA genes & 55 & $1.10 \%$ \\
rRNA operons & 2 & \\
Protein-coding genes & 4,944 & $98.90 \%$ \\
Pseudo genes & 264 & $5.28 \%$ \\
Genes with function prediction & 3,453 & $69,07 \%$ \\
Genes in paralog clusters & 804 & $16.08 \%$ \\
Genes assigned to COGs & 3,335 & $66.71 \%$ \\
Genes assigned Pfam domains & 3,508 & $70.17 \%$ \\
Genes with signal peptides & 1,038 & $20.76 \%$ \\
Genes with transmembrane helices & 1,209 & $24.18 \%$ \\
CRISPR repeats & 0 & \\
\hline
\end{tabular}



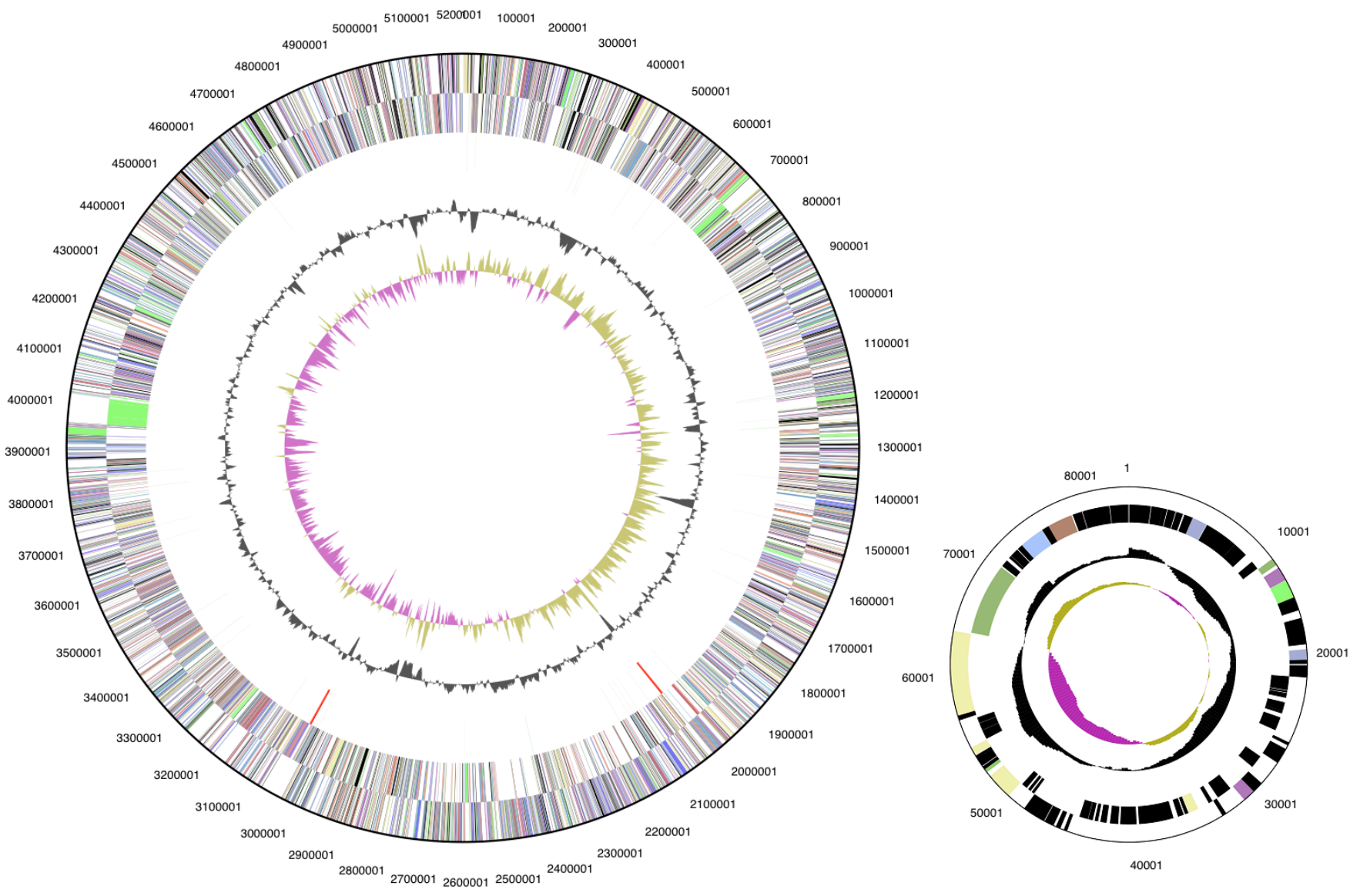

Figure 3. Graphical circular map of the chromosome and the plasmid. From outside to the center: Genes on forward strand (color by COG categories), Genes on reverse strand (color by COG categories), RNA genes (tRNAs green, rRNAs red, other RNAs black), GC content, GC skew.

Table 4. Number of genes associated with the general COG functional categories

\begin{tabular}{lrrl}
\hline Code & value & \%age & Description \\
\hline $\mathrm{J}$ & 164 & 3.3 & Translation, ribosomal structure and biogenesis \\
$\mathrm{A}$ & 1 & 0.0 & RNA processing and modification \\
$\mathrm{K}$ & 357 & 7.2 & Transcription \\
$\mathrm{L}$ & 238 & 4.8 & Replication, recombination and repair \\
$\mathrm{B}$ & 1 & 0.0 & Chromatin structure and dynamics \\
$\mathrm{D}$ & 28 & 0.6 & Cell cycle control, mitosis and meiosis \\
$\mathrm{Y}$ & 0 & 0.0 & Nuclear structure \\
$\mathrm{V}$ & 50 & 1.0 & Defense mechanisms \\
$\mathrm{T}$ & 158 & 3.2 & Signal transduction mechanisms \\
$\mathrm{M}$ & 133 & 2.7 & Cell wall/membrane biogenesis \\
$\mathrm{N}$ & 2 & 0.0 & Cell motility \\
$\mathrm{Z}$ & 1 & 0.0 & Cytoskeleton \\
$\mathrm{W}$ & 0 & 0.0 & Extracellular structures \\
$\mathrm{U}$ & 30 & 0.6 & Intracellular trafficking and secretion \\
\hline
\end{tabular}


Table 4 (cont.) Number of genes associated with the general COG functional categories

\begin{tabular}{lrrl}
\hline Code & value & \%age & Description \\
\hline O & 123 & 2.5 & Posttranslational modification, protein turnover, chaperones \\
C & 261 & 5.3 & Energy production and conversion \\
G & 197 & 4.0 & Carbohydrate transport and metabolism \\
E & 283 & 5.7 & Amino acid transport and metabolism \\
F & 90 & 1.8 & Nucleotide transport and metabolism \\
H & 172 & 3.5 & Coenzyme transport and metabolism \\
I & 270 & 5.5 & Lipid transport and metabolism \\
P & 202 & 4.1 & Inorganic ion transport and metabolism \\
Q & 210 & 4.2 & Secondary metabolites biosynthesis, transport and catabolism \\
R & 505 & 10.2 & General function prediction only \\
S & 286 & 5.8 & Function unknown \\
- & 1664 & 33.7 & Not in COGs \\
\hline
\end{tabular}

\section{Acknowledgements}

We would like to gratefully acknowledge the help of Susanne Schneider (DSMZ) for DNA extraction and quality analysis. This work was performed under the auspices of the US Department of Energy's Office of Science, Biological and Environmental Research Program, and by the University of California, Lawrence Berkeley National Laboratory under contract
No. DE-AC02-05CH11231, Lawrence Livermore National Laboratory under Contract No. DE-AC5207NA27344, and Los Alamos National Laboratory under contract No. DE-AC02-06NA25396, as well as German Research Foundation (DFG) INST 599/1-1.

While the manuscript was in editorial processing a $29^{\text {th }}$ species in the genus Gordonia was published: G. hankookensis [49], which is not featured in Figure 1.

\section{References}

1. Tsukamura M. Proposal of a new genus, Gordona, for slightly acid-fast organisms occurring in sputa of patients with pulmonary disease and in soil. J Gen Microbiol 1971; 68:15-26. PubMed

2. Goodfellow M, Alderson G. The Actinomycetegenus Rhodococcus: A Home for the 'rhodochrous' Complex. J Gen Microbiol 1977; 100:99-122. PubMed

3. Stackebrandt E, Smida J, Collins MD. Evidence of phylogenetic heterogeneity within the genus Rhodococcus: revival of the genus Gordona (Tsukamura). J Gen Appl Microbiol 1988; 34:341-348. doi:10.2323/jgam.34.341

4. Euzéby JP. List of bacterial names with standing in nomenclature.

http://www.bacterio.cict.fr/g/gordonia.html

5. Yoon JH, Lee J, Kang S, Takeuchi M, Shin Y, Lee S, Kang K, Park Y. Gordonia nitida sp. nov., a bacterium that degrades 3-ethylpyridine and 3- methylpyridine. Int J Syst Evol Microbiol 2000; 50:1203-1210. PubMed

6. Bell KS, Philp JC, Aw DWJ, Christofi N. The genus Rhodococcus. J Appl Microbiol 1998; 85:195-

210. PubMed doi:10.1046/j.13652672.1998.00525.x

7. Xue Y, Sun X, Zhou P, Liu R, Liang F, Ma Y. Gordonia paraffinivorans sp. nov., a hydrocarbondegrading actinomycete isolated from an oilproducing well. Int I Syst Evol Microbiol 2003; 53:1643-1646. PubMed doi:10.1099/ijs.0.02605$\underline{0}$

8. Kim KK, Lee CS, Kroppenstedt RM, Stackebrandt E, Lee ST. Gordonia sihwensis sp. nov., a novel nitrate-reducing bacterium isolated from a wastewater-treatment bioreactor. Int I Syst Evol Microbiol 2003; 53:1427-1433. PubMed doi:10.1099/ijs.0.02224-0

9. Soddell JA, Stainsby FM, Eales KL, Seviour RJ, Goodfellow M. Gordonia defluvii sp. nov., an ac- 
tinomycete isolated from activated sludge foam. Int J Syst Evol Microbiol 2006; 56:2265-2269. PubMed doi:10.1099/ijs.0.64034-0

10. Linos A, Steinbüchel A, Spröer C, Kroppenstedt RM. Gordonia polyisoprenivorans sp. nov., a rubber-degrading actinomycete isolated from an automobile tyre. Int I Syst Bacteriol 1999; 49:17851791. PubMed

11. Takeuchi M, Hatano K. Gordonia rhizosphera sp. nov. isolated from the mangrove rhizosphere. Int J Syst Bacteriol 1998; 48:907-912. PubMed

12. Kummer C, Schumann P, Stackebrandt E. Gordonia alkanivorans sp. nov., isolated from tarcontaminated soil. Int / Syst Bacteriol 1999; 49:1513-1522. PubMed

13. Shen FT, Goodfellow M, Jones AL, Chen YP, Arun AB, Lai WA, Rekha PD, Young CC. Gordonia soli sp. nov., a novel actinomycete isolated from soil. Int J Syst Evol Microbiol 2006; 56:2597-2601. PubMed doi:10.1099/ijs.0.64492-0

14. Kim SB, Brown R, Oldfield C, Gilbert S, Iliarionov S, Goodfellow M. Gordonia amicalis sp. nov., a novel dibenzothiophene-desulphurizing actinomycete. Int J Syst Evol Microbiol 2000; 50:20312036. PubMed

15. Kim SB, Brown R, Oldfield C, Gilbert SC, Goodfellow M. Gordonia desulfuricans sp. nov., a benzothiophene-desulphurizing actinomycete. Int J Syst Bacteriol 1999; 49:1845-1851. PubMed

16. Goodfellow M, Maldonado LA. 2006. The families Dietziaceae, Gordoniaceae, Nocardiaceae and Tsukamurellaceae. In: F Dworkin, S Falkow, KH Schleifer E Stackebrandt (eds), The Prokaryotes, Archaea, Bacteria, Firmacutes, Actinomycetes, vol. 3. Springer, New York.

17. Aoyama K, Kang Y, Yazawa K, Gonoi T, Kamei K, Mikami Y. Characterization of clinical isolates of Gordonia species in japanese clinical samples during 1998-2008. Mycopathologia 2009;

168:175-183. PubMed doi:10.1007/s11046-009$\underline{9213-9}$

18. Sng LH, Koh TH, Toney SR, Floyd M, Butler WR, Tan BH. Bacteremia caused by Gordonia bronchialis in a patient with sequestrated lung. J Clin Microbiol 2004; 42:2870-2871. PubMed doi:10.1128/JCM.42.6.2870-2871.2004

19. Werno AM, Anderson TP, Chambers ST, Laird HM, Murdoch DR. Recurrent breast abscess caused by Gordonia bronchialis in an immunocompetent patient. J Clin Microbiol 2005;
43:3009-3010. PubMed

doi:10.1128/JCM.43.6.3009-3010.2005

20. Richet HM, Craven PC, Brown JM, Lasker BA, Cox CD, McNeil MM, Tice AD, Jarvis WR, Tablan OC. A cluster of Rhodococcus (Gordona) bronchialis sternal-wound infections after coronary-artery bypass surgery. N Engl / Med 1991; 324:104-109. PubMed

21. Castresana J. Selection of conserved blocks from multiple alignments for their use in phylogenetic analysis. Mol Biol Evol 2000; 17:540-552.

PubMed

22. Lee C, Grasso C, Sharlow MF. Multiple sequence alignment using partial order graphs. BioinformatiCs 2002; 18:452-464. PubMed doi:10.1093/bioinformatics/18.3.452

23. Stamatakis A, Hoover P, Rougemont J. A Rapid Bootstrap Algorithm for the RAxML Web Servers. Syst Biol 2008; 57:758-771. PubMed doi:10.1080/10635150802429642

24. Liolios K, Mavromatis K, Tavernarakis N, Kyrpides NC. The Genomes On Line Database (GOLD) in 2007: status of genomic and metagenomic projects and their associated metadata. Nucleic Acids Res 2008; 36:D475-D479. PubMed doi:10.1093/nar/gkm884

25. Tsukamura M. Identification of mycobacteria. Tubercle, London 1967; 48:311-338. doi:10.1016/S0041-3879(67)80040-0

26. Tsukamura M. Adansonian classification of mycobacteria. J Gen Microbiol 1966; 45:253-273. PubMed

27. Field D, Garrity G, Gray T, Morrison N, Selengut J, Sterk P, Tatusova T, Thomson N, Allen MJ, Angiuoli SV, et al. The minimum information about a genome sequence (MIGS) specification. Nat Biotechnol 2008; 26:541-547. PubMed doi:10.1038/nbt1360

28. Woese CR, Kandler O, Wheelis ML. Towards a natural system of organisms: proposal for the domains Archaea, Bacteria, and Eucarya. Proc Natl Acad Sci USA 1990; 87:4576-4579. PubMed doi:10.1073/pnas.87.12.4576

29. Garrity GM, Holt JG. The Road Map to the Manual. In: Garrity GM, Boone DR, Castenholz RW (eds), Bergey's Manual of Systematic Bacteriology, Second Edition, Volume 1, Springer, New York, 2001, p. 119-169.

30. Stackebrandt E, Rainey FA, Ward-Rainey NL. Proposal for a new hierarchic classification sys- 
tem, Actinobacteria classis nov. Int J Syst Bacteriol 1997; 47:479-491.

31. Zhi XY, Li WJ, Stackebrandt E. An update of the structure and $16 \mathrm{~S}$ rRNA gene sequence-based definition of higher ranks of the class Actinobacteria, with the proposal of two new suborders and four new families and emended descriptions of the existing higher taxa. Int I Syst Evol Microbiol 2009; 59:589-608. PubMed doi:10.1099/ijs.0.65780-0

32. Editor L. Validation List No. 30. Validation of the publication of new names and new combinations previously effectively published outside the IJSB. Int J Syst Bacteriol 1989; 39:371.

33. Wink JM. Compendium of Actinobacteria. http://www.dsmz.de/microorganisms/wink_pdf/D SM43247.pdf/2009.

34. Agents B. Technical rules for biological agents www.baua.de TRBA 466.

35. Ashburner M, Ball CA, Blake JA, Botstein D, Butler H, Cherry JM, Davis AP, Dolinski K, Dwight SS, Eppig JT, et al. Gene Ontology: tool for the unification of biology. Nat Genet 2000; 25:25-29. PubMed doi:10.1038/75556

36. Chun J, Blackall LL, Kang S-O, Hah YC, Goodfellow M. A proposal to reclassify Nocardia pinensis Blackall et al. as Skermania piniformis gen. nov., comb. nov. Int / Syst Bacteriol 1997; 47:127-131. PubMed

37. Brandão PFB, Maldonado LA, Ward AC, Bull AT, Goodfellow M. Gordonia namibiensis sp. nov., a novel nitrile metabolising actinomycete recovered from an African sand. Syst Appl Microbiol 2001; 24:510-515. PubMed doi:10.1078/0723-2020$\underline{00074}$

38. le Roes M, Goodwin CM, Meyers PR. Gordonia lacunae sp. nov., isolated from an estuary. Syst Appl Microbiol 2008; 31:17-23. PubMed doi:10.1016/j.syapm.2007.10.001

39. Alshamaony L, Goodfellow M, Minnikin DE, Mordarska $\mathrm{H}$. Free mycolic acids as criteria in the classification of Gordona and the 'rhodochrous' complex. J Gen Microbiol 1976; 92:183-187. PubMed
40. Collins MD, Pirouz T, Goodfellow M, Minnikin DE. Distribution of menaquinones in actinomycetes and corynebacteria. J Gen Microbiol 1977; 100:221-230. $\underline{\text { PubMed }}$

41. Collins MD, Goodfellow M, Minnikin DE, Alderson G. Menaquinone composition of mycolic acid-containing actinomycetes and some sporoactinomycetes. J Appl Bacteriol 1985; 58:77-86. PubMed

42. Garton NJ, Sutcliffe IC. Identification of a lipoarabinomannan-like lipoglycan in the actinomycete Gordonia bronchialis. Arch Microbiol 2006; 184:425-427. PubMed doi:10.1007/s00203-005$\underline{0050-Z}$

43. List of growth media used at DSMZ: http://www.dsmz.de/microorganisms/media_list.p $\underline{\mathrm{hp}}$

44. Wu D, Hugenholtz P, Mavromatis K, Pukall R, Dalin E, Ivanova N, Kunin V, Goodwin L, Wu M, Tindall BJ, et al. A phylogeny-driven genomic encyclopedia of Bacteria and Archaea. Nature 2009; 462:1056-1060. PubMed doi:10.1038/nature08656

45. Sims D, Brettin T, Detter J, Han C, Lapidus A, Copeland A, Glavina Del Rio T, Nolan M, Chen F, Lucas $\mathrm{S}$, et al. Complete genome sequence of Kytococcus sedentarius type strain $\left(541^{\top}\right)$. Stand Genomic Sci 2009; 1:12-20. doi:10.4056/sigs.761

46. Anonymous. Prodigal Prokaryotic Dynamic Programming Genefinding Algorithm. Oak Ridge National Laboratory and University of Tennessee 2009 http://compbio.ornl.gov/prodigal/

47. Pati A, Ivanova N, Mikhailova, N, Ovchinikova G, Hooper SD, Lykidis A, Kyrpides NC. GenePRIMP: A Gene Prediction Improvement Pipeline for microbial genomes. (Submitted).

48. Markowitz VM, Ivanova NN, Chen IMA, Chu K, Kyrpides NC. IMG ER: a system for microbial genome annotation expert review and curation. Bioinformatics 2009; 25:2271-2278. PubMed doi:10.1093/bioinformatics/btp393

49. Park S, Kang SJ, Kim W, Yoon JH. Gordonia hankookensis sp. nov., isolated from soil. Int / Syst Evol Microbiol 2009; 59:3172-3175. PubMed doi:10.1099/ijs.0.011585-0 